YEARBOOK

of ANTITRUST

and REGULATORY

STUDIES

www.yars.wz.uw.edu.pl
Peer-reviewed scientific periodical, focusing on legal and economic issues of antitrust and regulation. Creative Commons Attribution-No Derivative Works 3.0 Poland License.

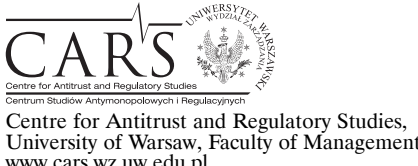

www.cars.wZ.uw.edu.pl

\title{
What Do Limitation Periods for Sanctions in Antitrust Matters Really Limit?
}

\author{
by \\ Ondrej Blažo*
}

\section{CONTENTS}

I. Introduction

II. Consequences of anti-competitive behaviour in Slovak jurisdiction and competences of the Antimonopoly Office of the Slovak Republic

III. Sanction system in the Slovak Republic and position of sanctions imposed by the AMO therein

IV. Slovak jurisprudence in administrative sanction cases and limitation periods

V. Common features and differences between powers of the AMO and other sanction bodies in Slovakia

VI. EU competition law and development of case-law

VII. Czech Cathode Tubes cartel case and similarity between Slovak and Czech regulation

VIII. Conclusions

\section{Abstract}

Limitation periods represent a legal safeguard for a person who has once broken the law in order not to be put at risk of sanctions and other legal liabilities for an indefinite amount of time. By contrast, public interest can sometimes require that a person who has committed a serious breach of law cannot benefit from limitation periods and that it is necessary to declare that the law had indeed been infringed and that legal liability shall be expected irrespective of the passage of time.

* Ondrej Blažo, PhD, Institute of International Affairs and Comparative Law, Faculty of Law, Comenius University in Bratislava. 
This article aims to answer the question whether limitation periods for sanctions attached to competition restricting practices by Slovak competition law also limit the powers of its competition authority to declare the illegality of illicit behaviour or to prohibit it. Although this question can arise, and has done so already, as a defence in antitrust proceedings, as well as the fact that an answer to this question can potentially, as well as actually, affect rights of undertakings which have broken competition rules, Slovak jurisprudence cannot be seen as explicit in answering this question.

\section{Résumé}

Les délais de prescription représentent une garantie juridique pour éviter que celui qui a violé la loi soit pour toujours exposé à la contrainte d'une sanction ou d'un autre type de responsabilté juridique. Toutefois, dans certains cas, il est dans l'intérêt public que la personne qui a gravement enfreint la loi ne puisse pas bénéficier du délai de prescription et qu'il soit possible de constater la violation du droit et d'engager la responsabilité juridique.

Le présent article essaie de répondre à la question fondamentale, celle de savoir si les délais de prescription prévus, dans le droit slovaque actuel, pour infliger des sanctions pour accords limitant la concurrence ou pour abus de position dominante sont, également, en situation de limiter la compétence de l'autorité slovaque de la concurrence de constater l'illégalité d'une démarche d'une entreprise ou sa compétence d'interdire une telle démarche.

Même si cette question peut être posée, ou a déjà été posée, en défense contre les démarches anti-cartel et la réponse à la question peut, potentiellement mais aussi réellement, avoir une influence sur les droits de l'entreprise qui a violé les règles de concurrence, la jurisprudence slovaque donne une réponse claire à cette question.

Classifications and key words: competition law; antitrust procedure; sanctions; administrative responsibility; Slovakia; EU law; limitation period; criminal law; private enforcement; legal certainty; safeguards; powers of competition authority; European Commission.

\section{Introduction}

Limitation periods represent a legal safeguard for a person who has once broken the law in order not to be endangered by sanctions and other legal liabilities for an indefinite amount of time after there is no longer 'the need of response in terms of both general and individual prevention'1. On the other

${ }^{1}$ E. Burda, J. Čentéš, J. Kolesár, J. Záhora, Trestný zákon. V̌seobecná čast. Komentár. I. Diel, Praha 2010, p. 595. 
hand, public interest can sometimes require that a person who has committed a serious legal infringement cannot benefit from limitation periods and that it is necessary to declare that the law has been broken and legal liability shall be expected irrespective of the timeframe of the infringement.

This article aims to answer the basic question whether limitation periods set by Slovak competition law for sanctions associated with the participation in competition restricting agreements and abuse of dominance also limit the powers of the Slovak competition authority to declare the illegality of illicit behaviour of undertakings or to prohibit such behaviour. Although this question can arise, and has in fact done so already, as a defence in antitrust proceedings and an answer to this question can potentially, as well as actually, affect rights of undertakings that have broken competition rules, Slovak jurisprudence cannot be considered explicit in answering this question.

In order to find an answer to this question, this article compares the regulation of administrative offences sanctioned by Slovak competition law with the regulation of other offences in the Slovak legal regime, especially other administrative offences and crimes. Considered will also be the impact of limitation periods on the power to commence sanction proceedings, to continue such proceeding, to declare the illegality of certain behaviours or to impose sanctions.

The article compares also the powers of certain bodies acting within the Slovak institutional framework with the powers of its competition authority with respect to the declaration of the illegality of illicit behaviour and the imposition of sanctions. This analysis takes note of several judgements delivered in cases dealing with administrative sanctions and responsibility for administrative offences (e.g. in competition or customs matters).

On this basis, two fundamental yet contradicting positions (hypothesis) will be presented and tested in conditions of competition law vis-à-vis the purpose of competition, its special features and also the relation to private enforcement.

Assessed further on will be the similarities and differences between Slovak competition law and that of the EU and of the Czech Republic. These two jurisdictions provide instructive jurisprudence in this context including, inter alia, ECL judgments in the GVL case (case 7/82), the Sumitomo Chemicals, Sumika Fine Chemicals case (joined cases T-22/02 and T-23/02), and in the Pergan case (T-474/04).

This article is meant to find a way out of the maze of arguments concerning the issue at stake and give a firm answer to the given question - an answer fully supported by theoretical analyses and jurisprudential argumentation. 
Incidentally, the relevance of this issue has recently surfaced one again because the Slovak competition authority is currently dealing with the $C R T$ Cartel $^{2}$ which is similar to the Cathode Tubes Cartel case dealt with by the Czech authority.

\section{Consequences of anti-competitive behaviour in Slovak jurisdiction and competences of the Antimonopoly Office of the Slovak Republic}

The Slovak legal order attaches both private law and public law consequences with anti-competitive behaviour. The main private law consequences of restrictive practices are the legal nullity of any act that violates competition rules and damages liability. Damages for harm caused by competition law infringements can be claimed in Slovakia under the rules of the Commercial Code $^{3}$ because such violations constitute an infringement of the general rule laid down therein: the obligation to observe legally binding provisions on economic competition and the obligation not to abuse participation in such economic competition ${ }^{4,5}$. Although several actions for damages were filed in Slovakian courts already, not one final judgment on claims for damages in competition matters has yet been delivered ${ }^{6}$. For that reason, the duty to pay damages cannot be considered an immediate threat deterring from competition violations in the Slovak competition framework.

The most serious public-law consequence of competition law infringements derives from the Slovak Penal $\operatorname{Code}^{7}$ that condemns the crime of abuse of

2 See press release of 11/11/11'Antimonopoly Office of the Slovak Republic fined a cartel', available at http://www.antimon.gov.sk/135/4495/antimonopoly-office-of-the-slovak-republicfined-a-cartel.axd.

3 Act No. 513/1991 Coll. as amended.

$4 \S 41$ of the Commercial Code.

5 The notion 'abuse of participation in economic competition' can sound strange but it might be a heritage of transitional period after the fall of Communist regime when certain fear of free market economy and deregulation appeared. It is clear that participation in economic competition itself cannot be abusive and merely some unfair practices within the competitive rivalry can be considered abusive. Albeit this notion is illogical and wrong, even in Slovak, I will use it within the presented paper since there is no equivalent to use in Slovak legal order and no corresponding notion in English-speaking countries. The notion "abuse of participation in economic competition" covers unfair competition practices and also practices contrary to competition (antitrust) rules.

6 P. Demčák, 'Pohlad a doterajšie skúsenosti Protimonopolného úradu SR', [in:] Súkromnoprávne vymáhanie sútažného práva/Private Enforcement of the Competition Law, Collection of Papers from the International Conference, Bratislava 2010, p. 65.

7 Act No. 300/2005 Coll. Penal Code as amended (hereafter, Penal Code). 
participation in economic competition under penal sanctions. However, it is impossible to find even one case in Slovakia where a natural person has actually been imprisoned because of a competition law infringement. For this reason, criminal sanctions for competition law offences are not seen as an effective deterrent in Slovakia. Liability for administrative offences and the imposition of administrative sanctions remains, therefore, the most frequent public-law consequence of competition law violations.

The majority of the responsibility for the enforcement of Slovak competition policy is placed on its competition authority. The Antimonopoly Office of the Slovak Republic (hereafter, AMO) was established as a central administrative body responsible for the protection and promotion of economic competition. Under $\S 22(1)$ of the Act on the Protection of Competition ${ }^{8}$ (hereafter, APC), the authority is empowered to issue decisions stating that: an undertaking's conduct or activity is prohibited pursuant to the APC or other special legislation (e.g. EU competition rules); to decide on the imposition of an obligation to refrain from such conduct and the obligation to remedy the unlawful state of affairs [subpar. b)]; and to proceed and decide on all matters regarding the protection of competition ensuing from the provisions of the APC or other special legislation [subpar. d)].

The provisions of $\S 4(1)$ APC prohibit agreements restricting competition (unless they are exempted under competition rules) while § 8(6) APC prohibits the abuse of a dominant position. The Act does not include any rules similar to those of Article 1(1) and 1(3) of Council Regulation (EC) No. 1/2003 whereby any practice of an undertaking caught by Article 101 or 102 of the Treaty on Functioning of the European Union (hereafter, TFEU) shall be prohibited, no prior decision to that effect being required. The absence of such provisions in the Act does not mean, however, that prior administrative decision is necessary for considering restrictive practices as illegal in Slovakia. A decision adopted pursuant to $\S 22(1)$ b) APC declaring a given conduct or activity as prohibited pursuant to Slovak competition rules is, therefore, merely of declaratory nature. In other words, the AMO can declare the prohibition of given conduct provided it is prohibited ex lege.

The Act itself does not contain a definition of what constitutes an administrative offence against competition (unlike some more modern Slovak laws, which do contain definitions of their respective administrative

8 Act No. 136/2001 Coll. on Protection of Competition and on Amendments and Supplements to Act of the Slovak National Council No. 347/1990 Coll. on Organization of Ministries and Other Central Bodies of State Administration of the Slovak Republic, as amended.

${ }^{9}$ Council Regulation (EC) No. 1/2003 of 16/12/02 on the implementation of the rules on competition laid down in Articles 81 and 82 of the Treaty, OJ [2003] L 1/1. 
offences $^{10}$ ) and the term itself is only used in its sixth part which is entitled 'Liability for administrative offences' and includes the provisions of $\S 38$ which regulate fines. Pursuant to $\S 38(1)$ APC, the AMO shall impose fines, inter alia, for violations of $\S 4(1)$ and $\S 8(6)^{11}$ APC, of up to $10 \%$ of the scrutinised undertaking's annual turnover. Despite the lack of a definition of a competition offence in the APC, such definition can easily be derived from the wording of the powers of the competition authority with respect to the imposition of fines. Accordingly, an undertaking that violates $\S 4(1)$ APC and/ or 101 TFEU (takes part in a prohibited competition restricting agreement) or $\S 8(6)$ and/or 102 TFEU (abuse of dominance) commits an administrative offence. The power of the AMO to impose fines is not explicitly listed in the recitals of $\S 22$ APC, which contains powers and duties of the AMO, but is included in the general provision of subparagraph d). For that reason, it is necessary to distinguish the power to adopt a decision declaring that a given conduct is prohibited [subpar. b)] and the power to impose a fine [subpar. d)] despite the fact that these two powers are closely related and usually executed together.

The AMO's power to impose an administrative fine is statute-barred by the APC as follows: 'The Office may impose fines pursuant to paragraphs 1 to 3 and 5 within four years from the commencement of the proceedings. However, the Office may impose these fines within eight years from the day of the violation of the provisions of this Act and/or the provisions of special legislation, the failure to fulfil a condition or the violation of an obligation or commitment imposed by a decision of the Office; in the event of a continuing administrative offence or lasting administrative offence, the time limit shall begin on the date on which the violation last occurred'12.

However, the APC does not contain any other provisions on limitation periods concerning the AMO's other powers. The question arises, therefore, whether limitation periods set out for the imposition of administrative fines also limit the powers of the Slovak competition authority to declare the illegality of a given illicit behaviour or to prohibit such behaviour. In other words, it is not clear how does the provision of $\S 38(8)$ APC affect the powers of the AMO under $\S 22((1) \mathrm{b})$ APC.

An overview of limitation periods applicable to other consequences of restrictive behaviours is not helpful in answering this question since there is no cross-reference between the APC and Slovak legislation on private or criminal law liability.

\footnotetext{
10 See e.g. Act No. 563/2009 Coll. Tax Rules of Procedure, $\S 154$ and 155.

11 This provision also empowers the AMO to impose fines for violations of procedural and merger rules.

$12 \S 38(8)$ APC.
} 
Anti-competitive practices are prohibited by competition rules - there is no limitation period after which such behaviour is not considered to be prohibited. The nullity of proscribed acts can clearly not be legalized by the mere passage of time - competition rules provide no exemption to this rule. However, the civil law right to claim damages falls under the limitations of the Commercial Code and is statute-barred upon the expiry of a four-year limitation period that begins on the day when the aggrieved (injured) party learned, or could have learned, of the damage and of the identity of the party liable for compensation; however, it shall expire no later than ten years from the day when such an infringement occurred ${ }^{13}$.

The limitation period for prosecuting the crime of abuse of participation in economic competition is statute-barred after three years for misdemeanours and five years for felonies ${ }^{14}$. There is no interdependence between limitation periods designed for different kinds of public law consequences of competition law infringements. Moreover, the limitation period in criminal cases is shorter than it is in cases tried by administrative bodies while administrative law does not include provisions similar to penal rules pursuant to which an offender is regarded as having never committed a crime after the lapse of the specified limitation period.

Limitation periods for the consequences of restrictive behaviour can be both longer (right to claim damages) and shorter (criminal responsibility) than limitation periods designed for administrative offences. Their comparison clearly shows that the AMO's 'declaratory' decisions (issued after the lapse of the period for imposing administrative fines) can be helpful to private-law claims only.

It is useful to outline here the Slovak administrative sanction system overall and to compare the definitions of the powers of administrative bodies other than the AMO as well as the consequences of the lapse of limitation periods for the responsibility for administrative offences other than those related to competition matters. It is also worth testing the non-existence of an explicit limitation period for the issue of 'declaratory' decisions by administrative bodies vis-à-vis constitutional safeguards of legal certainty, on the one hand, and the requirement to protect and promote economic competition, on the other hand.

$13 \S 397$ and 398 Commercial Code.

$14 \S 87$ Penal Code. 


\section{Public-law sanction system in the Slovak Republic and position of the sanctions imposed by the AMO therein}

Types of public-law liability for wrongful acts can be divided into two groups:

1. liability for criminal offences - offences prosecuted and punished by an independent judiciary;

2. liability for administrative offences - offences 'prosecuted' and 'punished' by administrative bodies ${ }^{15}$.

All types of offences (all offences, notwithstanding how they are labelled or what body or institution deals with them), as well as all corresponding investigations and enforcement procedures, can, nevertheless, be subject to the rules provided by the Convention for the Protection of Human Rights and Basic Freedoms (ECHR), particularly Articles 6 and 7 thereof. That is so because the term 'criminal charge' used in the ECHR covers charges for any offence of a criminal nature (both crime and administrative offences ${ }^{16}$ ) if it fulfils the criteria set out by the European Court of Human Rights ${ }^{17}$. Even if certain sanctions are explicitly labelled as non-criminal by domestic legislation, they can still be subject to the broader definition of 'criminal' sanctions applicable under the ECHR ${ }^{18}$. Deeming administrative offences as 'criminal' (broader sense) logically results in the need to apply certain criminal law (narrower sense) principles, definitions and institutes within the administrative sanction procedure, especially when administrative law does not provide such explicit provisions ${ }^{19}$.

Criminal offences are codified in Slovakia in the Penal Code and represent a numerus clausus category (the Penal Code covers all types of crimes - felonies and misdemeanours - and all subject-matters of crimes; crimes are tried by

15 See e.g. J. Machajová, 'Zodpovednost' vo verejnej správe', [in:] P. Škultéty a kolektív, Správne právo hmotné, Všeobecná a osobitná čast', Bratislava 2000, pp. 131-136.

16 See e.g. L. Madleňáková, 'Probíhá v ČR řízení o uložení správních sankci a jejich ukládáni dle zásad Rady Evropy?' (2010) XLIII(2) Správní právo 65-89.

${ }^{17}$ For definitions of a criminal charge for the purpose of ECHR application regarding administrative offences see e.g. ECHR cases Adolf v. Austria, § 30; Öztürk v. Germany, § 49; Engel and others v. The Netherlands, §§ 82-83; Jussila v. Finland, § 38; Bendenoun v. France, § 47; Benham v. The United Kingdom, § 56.

18 See e.g. W. P. J. Wils, 'The Increased Level of EU Antitrust Fines, Judicial Review, and the European Convention on Human Rights' (2010) 33(1) World Competition 5-29; L. Ritter, W. D. Braun, F. Rawlinson, EEC Competition Law. A Practitioner's Guide, Deventer, Boston, 1991, p. 666.

19 See e.g. judgment of the Supreme Administrative Court of the Czech Republic of 22/02/05, No. 5A164/2002; judgement of the Supreme Court of the Slovak Republic of 03/05/11, case No. 3Sžh/3/2010. 
uniform procedure pursuant to rules of the Penal Proceeding Code ${ }^{20}$ ). By contrast, the law on administrative offences is neither systematic nor codified:

1. there is more than just one category of administrative offences;

2. there is no common code of procedural rules;

3. definitions of subject-matters of administrative offences lie in a variety of acts.

Minor offences constitute the first and most homologous category of administrative offences in Slovakia since their general features, conditions of application and procedural rules ${ }^{21}$ are set out by the Act of the Slovak National Council No. 372/1990 Coll. on Minor Offences as amended (hereafter, Minor Offences Act). Despite the adoption of the Minor Offences Act, the law on minor offences remained 'semi-codified' since provisions on liability for minor offences can be found in other, more specific legal acts also (e.g. sectorial legislation). The common features of minor offences, either listed in the Minor Offences Act or enacted by special legal acts, include:

1. an illegal behaviour shall be explicitly designated as a minor offence by law;

2. only natural persons older than 15 years can be liable for minor offences;

3. guilt of an offender shall be proven - a minor offence must be committed at least by negligence (provided the subject-matter of the specific minor offence does not require the proof of the intent of the offender).

Disciplinary offences represent the second group of administrative offences that can be committed by natural persons. They are, however, of no relevance for the topic of this article.

The so-called 'other administrative offences' constitute the third and at the same time least homogenous group of administrative offences in Slovakia. They can be defined in a negative way as neither crimes, nor minor offences, nor disciplinary offences. 'Other administrative offences' are not subject to a specific procedural act and no binding list of their 'common' features has been legally forumlated. The Act No. 71/1967 Coll. on Administrative Proceeding (Administrative Procedure Code), which provides specific procedural rules for particular offences ${ }^{22}$, is the only procedural act applicable to 'other administrative offences'. In fact, many of the so-called 'other administrative offences' are not even defined by the law - they are merely subject to a sanction in the form of an

20 Act No. 301/2005 Coll., as amended.

21 General rules of administrative procedure shall be applied if there are no necessary rules in the Minor Offences Act (i.e. subsidiary application of general rules of administrative procedure).

22 E.g. special procedural rules for offences regarding tax or financial market regulation, or special provisions complementing the general rules of the Administrative Procedure Code. 
administrative fine. Some common features of 'other administrative offences' can be deduced:

1. both natural and legal persons can be found liable for such offences;

2. mens rea is usually irrelevant - strict liability applies and exculpation is not possible, there are no liberation reasons (absolute strict liability);

3. sanctions for such offences are rather harsh.

Fines imposed by the AMO under $\S 38(1)$ APC represent a liability for an administrative offence that falls into the group of 'other administrative offences' since they do not match the features of criminal offences or that of minor or disciplinary offences (nor are they labelled in such way). Liability for administrative offences pursuant to the APC is strict (lack of intent or negligence is irrelevant) and all undertakings violating competition rules are subject to this liability - both natural and legal persons.

Incidentally, minor offences and administrative offences concerning competition share a number of common features:

1. from the procedural point of view, they are both dealt with under the rules of the Administrative Code, unless the Minor Offences Act or the APC provides otherwise;

2. from the point of view of constitutional safeguards, conditions associated by the ECHR with 'criminal charges' shall be followed in the case of both minor offences and competition related administrative offences.

A question remains, however. How useful can this systematization of competition offences be seeing as it can face two basic restrictions regarding the analysis of the effects of limitation periods? First, limitation periods for minor offences, as shown below, are laid down by special legislation - the Minor Offences Act. Second, ECHR's general rules on 'criminal charges' are more concerned with questions such as fair trial, right of defence, right to be heard and protection against self-incriminating than with the question of limitation periods.

\section{Slovak jurisprudence in administrative sanction cases and limitation periods}

Slovak courts dealt with the question of limitation periods in competition matters only once in the Východoslovenská vodárenská spoločnost' case. The Supreme Court of the Slovak Republic (hereafter, SCSR) ruled therein that subjective and objective statutory limitation periods do not apply to behaviour that was considered illegal - it applies, however, to the limitation period 
for the imposition of fines ${ }^{23}$. This approach could serve as a firm basis for Slovak competition enforcement practice, if it was not for that fact that it can be challenged by later jurisprudential developments in matters of other administrative offences.

As noted, Slovakia does not have a specific procedural regime for sanctioning competition infringements or a general code on administrative offences. The Minor Offences Act applies to minor offences committed by natural persons by negligence or intentionally only - such violations are declared as minor offences by law. It seems useful to outline the legal basis of the consequences of limitation periods in cases of minor offences before engaging in further jurisprudential analyses.

The operative part of a decision declaring that an infringement occurred and imposing a sanction (a 'condemning' decision) in a minor offences case must, inter alia, contain a description of the wrongful act, a declaration of guilt and the type and amount of the sanction ${ }^{24}$. Under § 6(1)f) of the Minor Offences Act, the appropriate administrative body shall stop its proceedings if liability for a minor offence ceased to exist. The authority is not allowed to proceed against a minor offence if more than two years have passed since the violation occurred ${ }^{25}$. It is clear that the relevant authority is thus neither allowed to continue proceedings where the limitation period expired nor to issue a 'condemning' decision thereafter. The administrative body responsible for the minor offence at hand shall therefore not declare liability or guilt if the limitation period passes. For this reason, the Minor Offences Act contains limitation periods for both the imposition of sanctions and the declaration that certain behaviour was illegal.

The SCSR has repeatedly dealt with the question whether the expiration of the right to impose a fine means also the expiration of the right to decide that a given act was illegal. The Court noted ${ }^{26}$ with respect to customs offences, that $\S 251$ of the Customs Code applicable at the time of the judgment was similar to $\S 20$ of the Minor Offences Act, despite the fact that it deals with a limitation period for imposing a fine (two-year subjective and six-year objective limitation period) and the fact that it was not named 'Expiry of Punishability'. The SCSR ruled, therefore, that the expiration of the period for the imposition of a fine results in the elimination of the punishability of the offence from the material point of view. From the procedural point of view, it shall thus result in ceasing of the proceedings in such cases. This approach

23 Judgement of the SCRS of 14/12/05, case No. 1 Sž 14/2004 (Východoslovenská vodárenská spolocnost', a.s./Protimonopolný úrad Slovenskej republiky).

$24 \S 77$ Minor Offences Act.

$25 \S 20$ Minor Offences Act.

26 Judgment of the SCRS of 28/01/05, case No. 2 Sž-o-KS 63/04. 
can be considered as established since it was later confirmed on a number of occasions with respect to diverse types of administrative offences such as transport matters ${ }^{27}$ or broadcasting ${ }^{28}$.

The SCSR stressed also that administrative offences and crimes shall be subject to the same principles because they both fulfil the criteria of Article 6(1) ECHR. The Court found a parallel here for its reasoning in the Slovak Penal Code and the Penal Proceeding Code. Under $\$ 96$ of the Penal Code, 'punishability of an act shall become statute-barred on the expiry of the limitation period'; at the same time, if punishability is statute-barred, criminal proceedings cannot be commenced or shall be stopped if already underway under $\S 9(1)$ a) of the Penal Proceeding Code. Any decision adopted after the expiration of the statutory limitation period (despite being set for the imposition of a fine), shall thus be declared null or a false-act because the administrative body at hand no longer has the right to adopt any type of decision. The SCSR noted therefore that the given authority is not empowered to merely declare the illegality of a given behaviour in terms of liability.

All this notwithstanding, a key question arises in this context of whether this conclusion is unconditionally applicable to competition offences also or whether it is not applicable because of the existence of a special exemption clause or some unique features that competition offences poses?

\section{Common features and differences between powers of the AMO and other sanction bodies in Slovakia}

Decision-making powers of courts in criminal cases and administrative bodies in minor offence matters are very similar. Pursuant to the Penal Proceeding Code and the Minor Offence Act, decision-making bodies have the power to adopt a single decision where they describe the action or conduct that represents an infringement, declare the offender's guilt and impose a sanction. After the expiry of the limitation period laid down by the Penal Code, any criminal responsibility ceases to exist. It is thus not possible to start prosecution or trial after that date while all existing proceedings shall be stopped. If there is no legal responsibility for the wrongful act, it is impossible for an authority to assess such behaviour. By contrast, the Minor Offences Act is silent on the question of responsibility for minor offences but orders the discontinuation of existing proceedings regarding time-barred minor offences. This procedural provision avoids any further consideration of the scrutinised

27 Judgment of the SCRS of 12/03/09, case No. 8 Sžo 147/2008.

28 Order of the SCSR of 08/06/10, case No. 2 Sžo/2009. 
practice - no decision can be adopted later on (guilt can no longer be declared or prohibited conduct described).

When it comes to 'other administrative offences' specific legislation describes merely the features of their subject-matter and specifies the associated sanctions. Many of these acts are in fact limited to the setting of the sanction only. Imposing a sanction (of pecuniary and non-pecuniary nature) is, therefore, the only power conferred by such legislation on the appropriate administrative bodies. The authorities have in all these cases an implicit power to declare that an administrative offence was committed but this power is closely and inseparably joined with the power to impose a sanction. This realisation is true in all matters except for competition law infringement where the AMO has the additional right to declare a violation, to prohibit it and to order to remedy the unlawful state of affairs.

Once an authority loses its power to impose a sanction because the limitation period expired, it is left with no other power to act and is obliged to stop the procedures. With respect to administrative offences, the situation of the AMO is the same. After the expiry of the limitation period, the Slovak competition authority has no longer the power to impose a fine and it thus has no longer the power to declare the guilt. As a result, the responsibility for the administrative offence expires. The uniqueness of competition offences lies, therefore, in the existence of separate powers of the enforcing administrative body - the AMO - that are not directly connected with fines and limitation periods set for them [§ 22(1)b) APC].

\section{EU competition law and case-law developments}

The Slovak legislator was broadly inspired by EU competition law when drafting domestic provisions. Similarly, European competition enforcement practice is followed not only in cases with EU dimension, where the need to ensure the uniform application of EU competition law is obligatory ${ }^{29}$, but also in domestic proceedings. Even in cases dealt purely under Slovak national law $^{30}$, the decisions of the AMO are often inspired and their arguments supported by the case-law of the European Commission and the jurisprudence of European courts. It is thus useful to consider EU experiences with respect to limitation periods.

${ }^{29}$ For the relation of Slovak and EU competition law see e.g. K. Kalesná, 'Národné právo a právo EÚ', [in:] K. Kalesná, O. Blažo, Zákon o ochrane hospodárskej sútaže. Komentár, Praha 2012, pp. 7-10.

30 E.g. decision of the Council of the AMO of 01/07/05, No. 2005/KH/R/2/073. 
In order to enforce the prohibition laid down by Articles 101 and 102 TFEU, Regulation 1/2003 empowers the European Commission:

1. to require the undertakings and associations of undertakings concerned to bring such infringement to an end (Article 7);

2. to order interim measures (Article 8);

3. to make undertaking's commitments binding on the undertakings (Article 9);

4. to impose fines on undertakings and associations of undertakings where, intentionally or negligently, they infringe Article 101 or 102 TFEU; or they contravene a decision ordering interim measures under Article 8; or they fail to comply with a commitment made binding by a decision pursuant to Article 9 (Article 23);

5. to impose on undertakings or associations of undertakings periodic penalty payments in order to compel them to put an end to an infringement of Article 101 or 102 TFEU, in accordance with a decision taken pursuant to Article 7; to comply with a decision ordering interim measures taken pursuant to Article 8; to comply with a commitment made binding by a decision pursuant to Article 9 (Article 24).

The powers conferred on the Commission by Articles 23 and 24 are subject to the limitation period specified in Article 25 of Regulation 1/2003.

The European Commission is not explicitly empowered by Regulation $1 / 2003$ to adopt a decision purely declaring that a violation of EU competition rules has occurred; incidentally, it was not empowered to do so by earlier Regulation No. 17 either ${ }^{31}$. However, L. Ritter, W. D. Braun and F. Rawlinson were quite clear in stating that the effect of limitation periods does 'not apply to declaratory prohibition orders without fines' ${ }^{32}$. In support of this thesis a number of declaratory decisions was listed ${ }^{33}$, which formally declared that an already ceased conduct did in fact take the form of an infringement of EU competition rules ${ }^{34}$.

The question of a separate power to declare that a conduct or action of an undertaking is prohibited under EU competition rules was first raised before the ECJ in $7 / 82 G V L^{35}$. The scrutinised Commission decision declared that some of GVL's behaviours constituted an abuse within the meaning of Article

31 Council Regulation No. 17 of 06/02/62, First Regulation implementing Articles 81 and 82 of the Treaty, OJ [1962] 13/204.

${ }^{32}$ L. Ritter, W. D. Braun, F. Rawlinson, EEC Competition Law..., p. 667.

33 E.g. Central Bureau voor de Rijwielhandel, OJ [1978] L 20/18; GVL, OJ [1985] L 370/49; Fire Insurance, OJ [1985] 35/20; EATE, OJ [1985] L 219/35; Flower Auctions Aalsmeer I, OJ [1988] L 262/27; Tetra Pak I, OJ [1988] L 272/27; Bayer Dental, OJ [1990] L 351/46.

${ }^{34}$ L. Ritter, W. D. Braun, F. Rawlinson, EEC Competition Law..., p. 691.

35 7/82 Gesellschaft zur Verwertung von Leistungsschutzrechten mbH (GVL) v Commission of the European Communities, ECR [1983] 483. 
86 of the Treaty Establishing European Communities (currently, Article 102 TFEU). Unlike the view ultimately taken by the ECJ regarding the existence of a separate power to declare that a conduct is prohibited without imposing a fine or ordering to refrain from such action/conduct, Advocate General Reischl ${ }^{36}$ proposed to refuse all of the arguments presented by the Commission in favour of the existence of such competences. He rejected the claims made by the Commission claims on the grounds that:

1. there was no explicit provisions for such decision in the EEC Treaty or in the implementing Regulation 17/6237;

2. under Article 3(1) of Regulation 17/62, the Commission was not competent to adopt a decision if the infringement has been brought to an end in good time;

3. there was nothing in the provisions of Article 3(1) of Regulation 17/62 to justify the interference - even on the basis that the major premise includes the minor - that conferred a power to adopt measures which did not relate exclusively to the termination of an infringement but were intended to punish past conduct and nor was it possible to make such inference from Article 15(2) of Regulation 17/62 (imposing sanction);

4. the Council did not wish to confer purely declaratory powers on the Commission since the draft regulation contained separate powers for adopting declaratory decisions and decisions requiring the termination of a violation, but the final text of Regulation 17/62 did not showing that the Council did not provide for a separation of powers;

5. the list of sanctions contained in Regulation 17/62 had to be regarded as closed and its extension by analogy was against the principles of criminal law and legal certainty;

6. a desired publicity effect alone could not establish a competence to adopt a decision;

7. regarding civil litigations, an adopted decision did not have precedential but merely evidential value;

8. a purely declaratory decision was not indispensable in order to deal effectively with the danger of recurrence;

9. Regulation $17 / 62$ did not provide for any power to take purely preventive measures;

10. no reasons for adoption of a declaratory decision were found in that particular case.

The Court ultimately opposed the opinion expressed by the Advocate General having no doubts that the Commission has indeed the power to adopt

36 Opinion of 16/11/82 in case 7/82 Gesellschaft zur Verwertung von Leistungsschutzrechten mbH (GVL) v Commission of the European Communities, ECR [1983] 510-521.

37 Valid also for Regulation 1/2003. 
a purely declaratory decision. The ECJ said that the power to take decisions which require undertakings to bring any established infringement to an end, and the power to take decisions imposing fines and periodic penalty payments in respect of an infringement, necessarily imply a power to make a finding that the infringement in question exists ${ }^{38}$. In comparison to the detailed reasoning of AG Reischl's opinion, the judgement did not give further explanations or reasons for its own findings. What the ECJ saw as the only remaining question before it was whether the Commission managed to show sufficient legal interest to justify the adoption of such decision in this case ${ }^{39}$. GVL's obligation to terminate the practice in question was not expressly confirmed by the Court. Ultimately it was the danger of recidivism and the resulting necessity to clarify the legal position on this issue that were seen by the ECJ as legitimate reasons for adopting a declaratory decision by the Commission ${ }^{40}$.

Similar reasoning was presented in a later case albeit this time, the Court did not prove benevolent in its assessment of the legitimate interest in issuing a declaratory decision. In the joined cases T-22/02 and T-23/02 Sumitomo Chemical, Sumika Fine Chemical ${ }^{41}$, the Court of First Instance first dealt with the scope of the notion of 'sanction' within the meaning of Regulation No. $2988 / 74^{42}$ setting out limitation periods in competition matters. The CFI dealt also with the relationship between the title of Article 1 Regulation 2988/74 and limitation periods - a reference which could suggest that the scope of the limitation period referred to in Article 1 exceeds the mere power to penalise violations, so as to also cover the possibility of bringing an action or initiating proceedings seeking merely to establish an infringement ${ }^{43}$. The CFI concluded that the term 'penalties' used in Regulation 2988/74 only covers pecuniary sanctions ${ }^{44}$. As a result, ' $[\mathrm{a}]$ decision finding an infringement is not a penalty within the meaning of Article 1(1) of Regulation No 2988/74 and is not therefore covered by the limitation period laid down by that provision' 45 . The power to find an infringement was thus considered autonomous and separate

38 Case 7/82 GVL, para. 23.

39 Case 7/82 GVL, para. 24.

40 Case 7/82 GVL, para. 27.

41 T-22/02 and T-23/02 Sumitomo Chemical Co. Ltd and Sumika Fine Chemicals Co. Ltd $v$ Commission of the European Communities, ECR [2005] II-04065.

42 Regulation (EEC) No. 2988/74 of the Council of 26/11/74 concerning limitation periods in proceedings and the enforcement of sanctions under the rules of the European Economic Community relating to transport and competition, OJ [1974] L 319/1.

43 T-22/02 and T-23/02 Sumitomo Chemical, Sumika Fine Chemical, paras. 39-63.

44 T-22/02 and T-23/02 Sumitomo Chemical, Sumika Fine Chemical, para. 60.

45 T-22/02 and T-23/02 Sumitomo Chemical, Sumika Fine Chemical, para. 61. 
from other powers of the Commission, subject only to the test whether a legitimate interest existed to take such actions ${ }^{46}$.

The CFI ultimately annulled the contested decision as far as it concerned the applicants because the Commission failed to consider whether it had a legitimate interest justifying the issue of a declaratory decision finding that the applicants have committed an infringement. According to the Court, the Commission thus committed an error of law. The authority justified its actions by the interest of clarifying the legal situation at hand, the need to promote exemplary behaviour on the market and discouraging recidivism. Given, however, the particularly serious nature of the infringements in question, and the interest in enabling the injured parties to bring matters before national civil courts, the CFI did not consider the Commission's arguments sufficient to fulfil the requirement to show a legitimate interest for issuing a declaratory decision. The Court stated that the justification provided by the Commission 'merely sets out in generic terms three premises, without demonstrating, by reference to the particular circumstances of the present case relating to the very serious and extensive infringements alleged against the applicants, that those premises are established and consequently establish its legitimate interest in adopting against the applicants a decision finding those infringements' ${ }^{47}$. The Court blamed the Commission that it:

1. has not specifically explained to the Court why the gravity and geographic scale of the infringements in question made it necessary to find, by the Decision, infringements which had come to an end in the particular case of the applicants;

2. has adduced no evidence whatsoever of the risk of recidivism on the part of the applicants;

3. has not given any indication, relating to the particular circumstances of the present case, of legal proceedings undertaken or even capable of being envisaged by third parties injured by the infringements. ${ }^{48}$

46 'Whilst under the system established by Regulation No 17 the Commission's power to find an infringement arises only implicitly, inasmuch as the express powers to order cessation of the infringement and to impose fines necessarily imply this power ( $G V L$ v Commission, para. 23), such an implied power is not however dependent solely on the exercise by the institution of those express powers. The Court acknowledged the existence of that implied power in a judgment - GVL v Commission - which concerned the legality of a Commission decision finding an infringement which had been brought to an end and imposing no fine. It is not therefore possible to deny that the power in question is autonomous, or that this autonomy is unaffected by the fact that the exercise of that power was made subject to the existence of a legitimate interest of the Commission' (T-22/02 and T-23/02 Sumitomo Chemical, Sumika Fine Chemical, para. 63).

47 T-22/02 and T-23/02 Sumitomo Chemical, Sumika Fine Chemical, para. 138.

48 T-22/02\&T-23/02 Sumitomo Chemical, Sumika Fine Chemical, para. 139. 
In the T-474/04 Pergan $^{49}$ case, the CFI confirmed again that the Commission has the power to adopt declaratory decision ${ }^{50}$ stressing, however, that the right for defence and presumption of innocence shall be retained even in such cases: 'the Commission cannot adopt a decision finding an infringement after expiry of the limitation period, where such a finding is not justified by the existence of a legitimate interest and where the undertaking concerned has no possibility of seeking review of that finding by the Community judicature ${ }^{51}$. Moreover, undertakings whose participation in an infringement is mentioned in a Commission decision shall be its explicit addressees; their involvement shall be declared in the operative part thereof and they shall be allowed to contest that decision in front of the Court. It is irrelevant in this context whether a fine was ultimately imposed or not.

A basic difference can be found when comparing Slovak and European provisions: the 'declaratory' power of the AMO is explicitly given to it by domestic legislation whereas the same power of the Commission is merely implicit. Neither of the jurisdictions considers, however, the declaration of an infringement to be a sanction for anti-competitive behaviour. Even AMO's duty to show a 'legitimate interest' in issuing declaratory decisions is not required by law or case-law. Arguments presented in EU jurisprudence can be used to explain the necessity of declaratory decision in Slovak competition cases.

Since procedural rules are neither unified nor harmonized across Europe, limitation periods applicable to competition cases vary from country to country. In the UK, for instance, the Competition Act 1998 does not limit the possibility to impose sanctions for competition law violations ${ }^{52}$. Even a comprehensive analysis of the laws of all European countries will therefore not help answer the questions posed herein. An analysis of the Czech practice is nevertheless useful because of its great similarity to Slovak provisions.

49 T-474/04 Pergan Hilfsstoffe für industrielle Prozesse GmbH v Commission of the European Communities, ECR [2007] II-04225.

50 The question of powers of the Commission to issue a decision after expiring limitation period was also raised in other organic peroxide case - T-120/04 Peroxidos Organicos v. Commission of the European Communities, ECR [2006] II-4441.

51 T-474/04 Pergan, para. 79.

52 Albeit Professor Whish referred to the application of the six-year limitation period laid down by the general rule of the Limitation Act 1980 (R. Whish, Competition Law. 6th Edition., Oxford, 2008, p. 400.); this argument was however refused by the Competition Appeal Tribunal in Quarmby Construction case (Judgement of the Competition Appeal Tribunal of 15/04/11, case No. 1120/1/1/09, Quarmby Construction Company Limited, St James Securities Holdings Limited $v$ Office of Fair Trading). 


\section{Czech Cathode Tubes cartel case and the similarity between Slovak and Czech regulation}

It is worth noting that the Slovak and Czech legal environments are very similar as they both derive from the earlier Czechoslovak regime. Administrative courts in sanction matters have accumulated similar jurisprudence - where statutory periods for the imposition of sanctions have lapsed, the authorities are not empowered to proceed. This approach was formulated in a number of cases concerning minor offences ${ }^{53}$, trade inspections ${ }^{54}$ or tax audits ${ }^{55}$.

Czech legislation on competition law enforcement procedure is also very similar to Slovak provisions. Pursuant to $\S 7(1)$ of the Act on Protection of Competition $^{56}$ (hereafter, CzAPC), if the Czech Office for the Protection of Competition (hereafter, OPC) finds that a prohibited agreement took place, it shall declare such fact in a decision by means of which it shall prohibit the performance of the agreement in the future. Under $\S 11(2)$ CzAPC, if the OPC finds that an abuse has been committed, it shall declare such fact in a decision and it shall prohibit such actions in the future. The OPC is also empowered to impose administrative fines for offences committed by natural persons and administrative offences of legal persons and natural persons-entrepreneurs pursuant to $\S 22$ and $\S 22$ a CzAPC respectively. Responsibility for administrative offences is subject to a limitation period pursuant to $\S 22 \mathrm{~b}(6) \mathrm{CzAPC}^{57}$.

53 See e.g - judgment of the Supreme Administrative Court of 15/12/05, case No. 3 As $57 / 2004$.

${ }^{54}$ Judgment of the City Court in Prague of 11/12/00, case No. 28 Ca 145/99: 'There is no other power given to an administrative body by the provision in question than to impose a sanction. (...) The administrative body is not empowered by law to decide separately on guilt like a court in criminal proceeding; the law gives it only the power to impose sanction. The City Court in Prague holds the opinion that if the administrative body decided that the applicant committed an illegal action by fulfilling the criteria of the body of an administrative offence but it did not impose sanctions for such infringement, such decision is a null administrative act because of the lack of competence to decide'.

55 Order of the Supreme Administrative Court of 31/08/05, case No. 2 Afs 144/2004: 'Illegal tax audit is for example (...) a tax audit executed in time when the period for levying a tax lapsed'.

56 In full: Act No. 143/2001 Coll. of 04/04/01 on the Protection of Competition and on Amendment to Certain Acts (Act on the Protection of Competition) as amended

57 'The responsibility for the administrative offence shall cease to exist if the administrative authority initiates administrative proceedings no later than 5 years following the day on which it learned of the administrative offence, however, no later than 10 years after the administrative offence was committed'. 
The Czech competition authority had no doubt that it was entitled to declare the existence of an infringement and prohibit anti-competitive behaviour pro futuro even when the period for the enforcement of administrative sanction had already passed ${ }^{58}$. This approach was confirmed by the Regional Court in Brno in its review of the OPC President's decision in Cathode Tubes cartel ${ }^{59}$. The Court provided here a broad reasoning for its conclusions and refused to be tied down by case-law regarding other than competition-related offences considering it to be not relevant to the scrutinised issue. The necessity to describe the actual infringement was identified as the reason for confirming the right of the OPC to declare that an undertaking has participated in a cartel $^{60}$, even if responsibility for the offence was already time-barred. The Court refused to accept the view that the necessity to respond to the offence disappears with the expiration of the limitation period in cases when the proceedings involve the conduct of all members of a cartel (even if some of them could no longer be punished). The Court confirmed, however, the general premise that the power of an administrative body to adjudicate guilt of a party to the proceedings expires together with the lapse of the period for imposing sanctions (not applicable in the case at hand).

The Regional Court in Brno confirmed also the dichotomy of the powers of the Czech competition authority and stressed the importance of declaratory decisions for competition protection: '(therefore) it is possible to agree with the defendant on its description of the specifics of CzAPC in the fields of legal regulation of other administrative offences, which goes alongside the power to declare and prohibit anti-competitive behaviour and power to punish such behaviour. This concept is not as absurd as the applicants claim. The autonomy of both of these elements of responsibility of cartel members for the committed offence not only derives from the lie out of CzAPC itself (...), which can be secondary, but from the very core of the broader responsibility of the defendant for the state of the competitive environment (...). This responsibility of the defendant can be fulfilled even by declaring and prohibiting anticompetitive behaviour in relation to such conduct even if not all participants can be subject to a sanction'.

58 E.g. in GIS cartel case (decision of the Chairman of the OPC of 24/04/07, No. R 059-070, 075-078/2007/01-08115/2007/310).

59 Judgment of the Regional Court in Brno of 23/02/12, case No. 62 Af 75/2010.

60 'The actions of the defendant after the lapse of the period for imposing a fine do not represent an enforcement of state power against the applicant a) but the only possible way to fulfil its duty to describe an offence as a behaviour of several competitors (...) to declare that the administrative offence occurred, prohibit such behaviour for the future and to punish such behaviour if the period for imposing fines had not terminated'. 
Because of the similarity of Czech and Slovak competition rules, as well as the similarity of their overall legal systems, the judgement of the Regional Court in Brno in the Cathode Tubes case ${ }^{61}$ can be instructive also within the Slovak legal framework. Although the court did not answer the question concerning the application of the power to declare and prohibit anticompetitive behaviour in general, it seems that it saw the possibility of an exemption from the general rule whereby such decision can be issued only if at least some parties to the proceeding can still be punished. The court remained silent about whether there could be any other reasons to continue proceedings even after the lapse of limitation periods regarding all members of the scrutinised cartel.

\section{Conclusions}

Limiting de facto the length of the sanction procedure by the limitation period for the imposition of fines is closely related to the right to a speedy trial. On the other hand, only the right to impose sanctions is statute-barred in order to prevent overly-long proceedings. Slovak legislation remained silent as far as AMO's power to issue 'declaratory' decision is concerned. It cannot be concluded, therefore, that the legislator meant to give the same level of protection against excessive length of sanction proceedings and in 'declaratory' matters. The Competition Appellate Tribunal reached similar conclusions regarding the impossibility of construing a duty to decide in reasonable time as an unexpressed limitation period (de facto) irrespective of the non-expressed will of the legislator to make such limitation: 'Whilst it is desirable that the OFT concludes its investigations as quickly as possible, it is not appropriate to suggest that proportionality requires the OFT to be subject to a de facto subjective and uncertain limitation period in circumstances where the Parliament did not intend there to be any such constraint on the OFT's powers' ${ }^{\prime}$. Therefore, infringing the right to a speedy trail does not entail the loss of the power to adopt a decision even if it can give grounds for other claims by the injured party (e.g. obligation to pay costs, to finish proceeding by decision). The administrative body can lose its powers because of an excessive

61 Although judgements of the regional court are final and effective, they can still be reviewed by the Supreme Administrative Court on the basis of a cassation request.

62 Judgment of the Competition Appeal Tribunal of 15/04/11, case No. 1120/1/1/09, Quarmby Construction Company Limited, St James Securities Holdings Limited v Office of Fair Trading, para. 56.

VOL. 2012, 5(7) 
length of proceeding only if the aim of such proceedings cannot be reached in that situation.

Although it seems that the AMO has the power to enforce its competences pursuant to $\S 22(1)$ (b) APC even after the expiration of the limitation period for imposing fines provided for under $\S 38(1)$ APC, there are at least three requirements that can limit the execution of this power:

1. the purpose of the APC - protection and promotion of economic competition that represents the ultimate criterion for the enforcement of all AMO's powers;

2. the need to comply with the principle of procedural economy - pursuant to $\S 3(3)$ of Administrative Procedure Code: 'Administrative authorities must ensure that administrative proceedings are economical and do not uselessly bother citizens and organizations'.

3. the need to comply with the principle of legality of administrative proceedings - pursuant to $\S 3(1)$ of Administrative Procedure Code: administrative bodies are obliged to "protect the interests of the State and society, the rights and the interests of citizens and organizations and require, in a consistent manner, the fulfilment of their duties'.

That is why every decision adopted by the AMO has to ultimately serve the protection or promotion of economic competition. Furthermore, it has to be adopted in an effective and economical manner and thus the total cost of AMO' pro-competitive intervention cannot outweigh its total possible welfare gain.

As an administrative body, the AMO shall keep a permanent check on whether it meets all criteria and prerequisites for administrative proceedings. After the expiry of the limitation period for imposing a fine, it might be gradually more and more difficult to fulfil these three principles. After over four years of investigations and/or eight years after the termination of a cartel participation, public intervention can be ineffective, slow and costly because neither enough evidence nor suitable data is likely to remain. Furthermore, can a declaratory decision after so long effectively contribute to the fulfilment of the purpose of the APC and AMO's tasks and thus, is the first of the criteria met? The Regional Court in Brno said that if at least one punishable cartel participant remains, there is an interest and duty to describe the cartel as a whole. The criterion of competition protection is therefore always met.

After the lapse of the right to impose a fine regarding all participants of a violation, AMO's ability to facilitate competition protection can drastically decrees (depending on the general market situation, existence of competitors, extent of possible damages and probability of recurrence). The AMO cannot impose in such decisions a fine and is not capable to retrieve any gains of the illegal conduct. On the other hand, such decisions can aid deterrence 
and legal certainty by helping to avoid similar infringements in the future and explain enforcement policy developments ${ }^{63}$. Gains of a purely declaratory decision must be balanced with the costs incurred by both the authority and the parties to the proceeding as well as with the burden put on the latter by the investigation. To commit

Although decisions issued by competition authorities are said to be important for follow-on claims, as the basis for an effective private enforcement of competition law, it is necessary to note that pursuant to $\S 135(1)$ of the Slovak Civil Procedure Code ${ }^{64}$ 'the courts shall be bound by the decisions of competent bodies establishing the occurrence of criminal offences, administrative infractions or other administrative offences punishable under separate legal provisions and their perpetrators' only. Decisions delivered before the lapse of limitation periods that declare responsibility for administrative offences can be used as a basis for court rulings in damages cases. Decisions that merely declare the existence of a past infringement (do not rule on responsibility) do not have such evidential powers. They provide a 'summary of evidence' only that must be reassessed by the civil court. It is worth recalling in this context an opinion presented by Advocate General Mazák in the Pfleiderer case. AG Mazák admitted that private enforcement of competition law is of low importance across Europe: 'Indeed so reduced is the current role of private actions for damages in that regard that I would hesitate in overly using the term 'private enforcement' ${ }^{65}$.

For these reasons, the concept of AMO's limited competence to adopt declaratory decisions after the lapse of its power to impose a fine (connected with the establishment of responsibility for a given administrative offence), closely resembles the 'legal interest' concept developed by ECJ jurisprudence. In general, irrespective of its power to impose a fine, the AMO has the power to adopt purely declaratory decisions. However, this power is lost if it is proven that such a decision does not represent an effective and economical means of protecting or promoting competition or if the proceedings are overly burdensome. If an intervention by AMO past the limitation period does not pass this test, it would be seen as a form of misconduct or an abuse of AMO's powers rather than justified law enforcement. As such, it should be ceased pursuant to $\S 32(2)$ (c) APC.

${ }^{63}$ E. De Smijter, L. Kjolbye, 'The Enforcement System under Regulation 1/2003', [in:] J. Faull, A. Nikpay, (eds.), The EC Law on Competition, 2nd edition, New York 2007, pp. $118-119$.

64 Act No 99/1963 Coll. Civil Procedure Code, as amended.

65 Opinion of AG Mazák delivered on 16/12/10, Case C-360/09 Pfleiderer AG v Bundeskartellamt. 
The analysis presented in this paper once again confirmed that the lack of a legislative act regulating uniformly the fundamental principles as well as key features of administrative offences results in a sea of doubt regarding an issue as important as the competences of particular administrative bodies, in this case the AMO.

A legal amendment formulating explicit rules in this field would clearly be the most appropriate way to solve this uncertainty. Among the ways to ensure maximal enforcement on the one hand, and avoid the wasting of resources on the other hand, could be the introduction of a three stage process for the AMO to 'lose' its powers after the lapse of limitation periods for the imposition of fines:

1. when it is still possible to impose a fine on at least one party to the administrative proceedings (e.g. at least one participant of the scrutinised cartel), the AMO shall retain its full competences to declare that the behaviour of every party to such proceedings was prohibited under the APC;

2. when is not possible to impose a fine on any of the parties, but the limitation period for damages claims at least towards one of the participants has not yet lapsed, then, in order to facilitate private litigation, the approach could be somewhat more complex; the AMO shall suspend its proceedings for a certain period of time (e.g. 6 months) and continue to issue a decision only if it receives an order from a court dealing with a damages action; otherwise the AMO shall discontinue its proceeding;

3. after the lapse of all limitation periods for damages claims, the AMO shall stop its proceeding.

Admittedly, such three stage approach is rather complicated and respects merely a part of 'legitimate interests'.

An alternative legislative approach could prepare a list of possible conditions ('legitimate interests') that the AMO would need to fulfil in order to continue its proceedings past the limitation period. The weakness of this solution is its potential rigidity.

The third and most flexible approach could require the AMO to show that a declaratory decision could contribute to the protection or promotion of economic competition.

The fourth possible way to deal with this issue would be to explicitly declare that there is no limitation period for 'declaratory' decisions.

However, the third and fourth solution, as well as leaving this issue as it currently stands (i.e. status quo) are very similar to each other as they all require the AMO to always check whether it still fulfils its duty to protect and promote economic competition. 


\section{Literature}

Burda E., Čentéš J., Kolesár J., Záhora J., Trestný zákon. Všeobecná čast. Komentár. I. Diel [Penal Code. General Part. Commentary. Volume I], Praha 2010.

Demčák P., 'Pohlad a doterajšie skúsenosti Protimonopolného úradu SR' ['Overview and Experiences of the Antimonopoly Office of the Slovak Republic'], [in:] Súkromnoprávne vymáhanie sútažného práva/Private Enforcement of the Competition Law, Collection of Papers from the International Conference, Bratislava 2010.

Faull J., Nikpay A (eds.), The EC Law on Competition, 2nd edition, New York 2007.

Kalesná K., Blažo O., Zákon o ochrane hospodárskej sútaže. Komentár [Act on Protection of Economic Competition. Commentary], Praha 2012.

Machajová J., 'Zodpovednoste vo verejnej správe', [in:] P. Škultéty a kolektív, Správne právo hmotné, Všeobecná a osobitná čast', Bratislava 2000.

Madleňáková L., 'Probíhá v ČR řízení o uložení správních sankci a jejich ukládáni dle zásad Rady Evropy?' ['Is the administrative sanction process and sentencing of sanctions in the Czech Republic harmonious with principles of the Council of Europe?'] (2010) XLIII(2) Správní právo.

Ritter L., Braun W. D., Rawlinson F., EEC Competition Law. A Practitioner's Guide, Deventer, Boston, 1991.

Whish R., Competition Law. 6th Edition, Oxford 2008.

Wils W. P. J., 'The Increased Level of EU Antitrust Fines, Judicial Review, and the European Convention on Human Rights' (2010) 33(1) World Competition. 